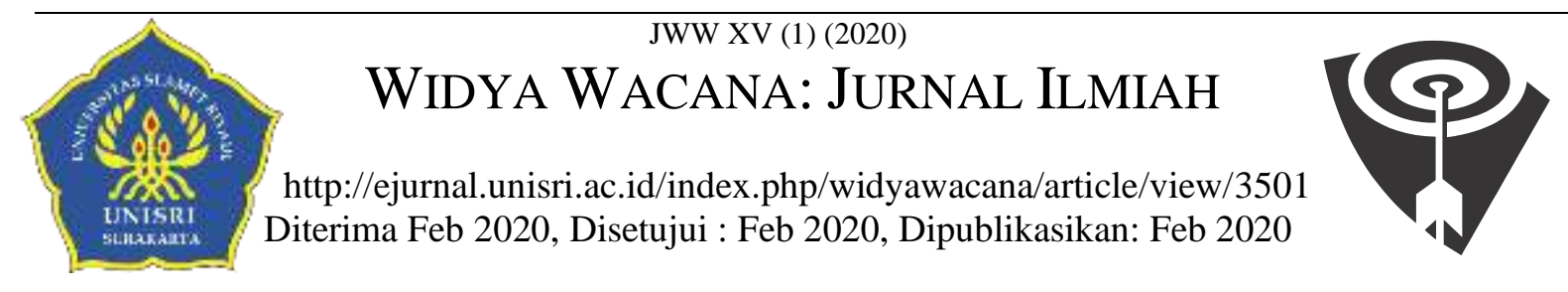

\title{
PENDIDIKAN KARAKTER KERJASAMA DALAM PEMBELAJARAN MATEMATIKA
}

\author{
Sri Rezeki Wulandari, Warlim Isya \\ Universitas Pendidikan Indonesia \\ Email: Rezekywulanday2025@upi.edu
}

\begin{abstract}
ABSTRAK
Matematika merupakan mata pelajaran yang wajib diikuti siswa di setiap jenjang pendidikan. Siswa dapat mengembangkan pengetahuan secara literasi dan numerasi melalui pembelajaran matematika. Namun konsep matematika yang abstrak menyebabkan sebagian siswa sulit memahami. Oleh karena itu, guru menggunakan model kooperatif untuk membantu siswa memahami konsep matematika sekaligus menanamkan pendidikan karakter kerja sama. Alasan terkuat pembelajaran matematika kooperatif karena yang dibutuhkan siswa dalam memahami konsep matematika bukan hanya kerja keras tetapi juga kerja sama. Melalui pembelajaran kooperatif, selain siswa dapat menyelesaikan soal, juga dapat menumbuhkan nilai karakter seperti bersahabat, toleransi, menghargai prestasi, tolong menolong, dan lainnya.
\end{abstract}

Kata Kunci : Pembelajaran matematika, pembelajaran kooperatif, nilai karakter kerjasama

\begin{abstract}
Mathematics is a subject that must be followed by students at every level of education. Students can develop literacy and numeracy knowledge through mathematics learning. But abstract mathematical concepts make it difficult for some students to understand. Therefore, the teacher uses a cooperative model to help students understand mathematical concepts while instilling the character of cooperation education. The strongest reason for cooperative mathematics learning is because what students need in understanding mathematical concepts is not only hard work but also cooperation. Through cooperative learning, in addition to students being able to solve problems, they can also grow character values such as friendship, tolerance, respect for achievement, please help, and others.
\end{abstract}

Keywords: Mathematics Learning, Cooperatif Learnig Model, collaboration character value.

\section{PENDAHULUAN}

Matematika merupakan mata pelajaran yang wajib diikuti siswa di setiap jenjang pendidikan. Siswa dapat mengembangkan pengetahuan secara literasi dan numerasi melalui pembelajaran matematika. Pengetahuan literasi dan numerasi ini harus sejalan karena keduanya merupakan dasar dalam kehidupan manusia (Alwasilah, 2015). Namun konsep matematika yang abstrak menyebabkan sebagian siswa sulit untuk memahaminya. Padahal aspek yang paling penting adalah pemahaman dan ini merupakan inti dari pembelajaran Matematika, karena siswa akan lebih mampu menyelesaikan suatu permasalahan dengan pemahaman bukan dengan hapalan (Carpenter, 1992; Hudojo ,1998; Katona, 1992) dalam (Masjudin, 2016). Oleh karena itu, guru menggunakan model kooperatif untuk membantu siswa memahami konsep matematika sekaligus melaksanakan penguatan pendidikan karakter.

Dalam pembelajaran kooperatif yang di gunakan guru dalam proses pembelajaran Matematika, selain dapat membantu siswa mengembangkan pengetahuan literasi dan numerasi juga sebagai suatu sarana untuk menanamkan pendidikan karakter kerjasama. Kerjasama memberikan 
kontribusi lebih besar sekitar $80 \%$ dari pada kecerdasan intelektual yang hanya 20\% (Goleman, 2005) dalam (Sardadevi \& Winarti, 2017). Ini menunjukkan bahwa kecerdasan intelektual dapat terbantu dengan pembelajaran yang di lakukan dengan menerapkan karakter kerjasama.

Sebagaimana dijelaskan dalam Permendikbud (2018, hal. 5) pada pasal 6 ayat 2 poin a) mengintegrasikan nilai-nilai karakter dalam proses pembelajaran secara tematik atau terintegrasi dalam mata pelajaran sesuai dengan isi kurikulum. Ini berarti bahwa semua penguatan pendidikan karakter dapat diintegrasikan pada semua mata pelajaran dan semua guru memiliki tanggung jawab yang sama untuk menanamkan pendidikan karakter kepada siswa.

Alasan terkuat pembelajaran matematika secara kooperatif karena yang dibutuhkan siswa dalam memahami konsep matematika bukan hanya kerja keras tetapi juga kerja sama. Pembelajaran kooperatif yang melibatkan siswa berinteraksi secara penuh dan bekerja sama dengan teman dapat menumbuhkan nilai karakter yang lain seperti bersahabat, toleransi, menghargai prestasi, tolong menolong, dan lainnya (Rosyidah, 2016). Selain itu kerjasama dalam pembelajaran lebih memudahkan siswa memahami konsep materi pelajaran karena siswa dalam kelompok belajar saling berbagi atau mentransfer pengetahuan, sehingga tujuan pembelajaran lebih cepat tercapai. Kerja sama dapat mempercepat tujuan pembelajaran, sebab pada dasarnya suatu komunitas belajar selalu lebih baik hasilnya daripada beberapa individu yang belajar sendiri-sendiri.

Berdasarkan uraian di atas, penulis ingin memaparkan beberapa hal terkait pendidikan karakter dalam pembelajaran Matematika yang pertama, bagaimana pendidikan karakter kerjasama dalam pembelajaran Matematika?. Kedua, nilai-nilai karakter apa saja yang menjadi indikator dalam pembelajaran?. Ketiga, kemampuan apa saja yang dapat ditingkatkan siswa melalui pendidikan kerjasama dalam pembelajaran Matematika?.

\section{KAJIAN PUSTAKA \\ Pendidikan Karakter}

Jones et al. (1999) mendefinisikan pendidikan karakter merupakan pendidikan yang mencakup ranah kognitif, afektif, dan psikomotorik melalui perilaku. Ranah kognitif yang dimulai dari mengetahui sesuatu yang baik, afektif dengan mencintai sesuatu yang baik, dan psikomotorik dengan melakukan hal-hal yang baik (Williams, 2000, hal. 33).

Makna dari pendidikan karakter itu sendiri adalah pendidikan yang terintegrasi dengan pembelajaran yang terjadi pada semua mata pelajaran (Kesuma, 2012: 5). Penguatan pendidikan karakter dapat di lakukan dalam proses pembelajaran di semua mata pelajaran. Dalam (Tafsir, 2017) pendidikan karakter merupakan pendidikan yang didalamnya memuat tiga hal yaitu bagaimana siswa mengetahui tentang kebaikan (knowing good), mencintai kebaikan (loving the good), dan kemudian dengan pengetahuan dan kecintaan akan kebaikan ini dapat diaplikasikan dengan melakukan kebaikan (doing the good).

Pendidikan karakter sejatinya merupakan pendidikan sepanjang hayat yang meliputi tiga komponen karakter baik didalamnya yaitu pertama, pengetahuan moral yang meliputi enam aspek penting yaitu kesadaran moral, mengetahui nilai moral, penentuan perspektif, pemikiran moral, pengambilan keputusan, dan pengetahuan pribadi. Kedua, perasaan moral yang penting bagi setiap orang karena tidak jaminan bagi setiap orang untuk melakukan tindakan yang baik hanya dengan mengetahu apa yang benar saja. Perasaan moral meliputi hati nurani, harga diri, empati, mencintai hal yang baik, kendali diri, dan kerendahan hati. Ketiga, tindakan moral sebagai outcome dari dua komponen karakter baik sebelumnya karena untuk apa hanya mengetahui dan menyadari tanpa adanya aksi. Tindakan moral meliputi kompetensi, keinginan, dan kebiasaan (Lickona, 2019).

\section{Nilai Karakter Kerjasama}

Nilai merupakan pandangan atau perspektif seseorang terhadap sesuatu yang baik, benar, indah, bijaksana yang 
kemudian dijadikan sebagai tolak ukur atau pedoman dalam bersikap maupun bertindak (Hakam \& Nurdin, 2016). Karakter menurut Aristoteles "kehidupan dengan melakukan tindakan-tindakan yang benar sehubungan dengan diri seseorang dan orang lain" (Lickona, 2019). Karakter adalah cara berpikir dan berperilaku yang menjadi ciri khas masing-masing individu untuk hidup dan bekerja sama, baik dalam lingkup keluarga, masyarakat, bangsa, dan negara (Lonto et al., 2018). Karakter dikatakan sebagai proses "ukiran". Karakter dalam diri setiap individu tidak serta merta ada sejak individu itu dilahirkan, tetapi karakter ada melalui proses pembinaan dan bimbingan yang dikembangkan melalui proses yang panjang dan melibatkan pendidikan serta di lakukan secara terus menerus (Komalasari, 2012, hal. 91).

Coakley mendefinisikan kerjasama sebagai proses sosial melalui performa yang dinilai dan dihargai dengan istilah sekumpulan prestasi dari sekelompok orang yang bekerjasama untuk mencapai tujuan tertentu (Mylsidayu, 2015:61) dalam (Fauzani, 2018). Hakikat kerjasama adalah aktivitas yang ditujukan dalam bentuk kerja kelompok antar teman yang mana didalamnya terdapat perbedaan pendapat dan dapat menyatukan pendapat tersebut menjadi satu (Kusuma, 2018).

Jadi, nilai karakter kerjasama merupakan kegiatan yang di lakukan secara berkelompok dimana masing-masing anggota kelompok memiliki perbedaan baik pendapat, gagasan, kemampuan, dan lain sebagainya, tetapi mereka harus dapat menyatukan segala perbedaan yang ada menjadi satu untuk mencapai tujuan yang sama.

\section{Pembelajaran Matematika}

Bruner menyatakan bahwa dalam pembelajaran matematika siswa mempelajari tiga hal yaitu pertama, belajar tentang konsep-konsep dan struktur-struktur matematika yang terdapat dalam materi yang dipelajari serta hubungan antara konsepkonsep dan struktur-struktur matematika itu. Kedua, tidak hanya pada melatih keterampilan dan menghafal fakta, tetapi pada pemahaman konsep. Ketiga, memerlukan keaktifan anak dalam proses belajar secara penuh (Masjudin, 2016).

Pembelajaran Matematika sangat penting, karena memiliki beberapa tujuan sebagaimana telah dijelaskan dalam Kurikulum Tingkat Satuan Pendidikan (Depdiknas, 2006: 345) dalam (Linuhung \& Sudarman, 2019) dimana siswa dapat mengembangkan kemampuan memahami dan menjelaskan konsep matematika, menggunakan penalaran, memecahkan masalah, mengkomunikasikan gagasan dengan simbol matematika, memiliki sikap menghargai dalam kehidupan, dan minat dalam mempelajari matematika.

The National Council of Teachers of Mathematics (Yuniawatika, 2011) dalam (Fadhilaturrahmi, 2018) menetapkan bahwa terdapat 5 kemampuan yang perlu dimiliki siswa melalui pembelajaran matematika yang tercakup dalam standar proses yaitu pemecahan masalah (problem solving), penalaran dan pembuktian (reasoning and proof), komunikasi (communication), koneksi (connection) dan representasi (representation).

\section{HASIL}

Hasil telaah literatur menunjukkan bahwa pembelajaran Matematika dapat digunakan sebagai pembinaan karakter kerjasama. Hal ini ditunjukkan dari beberapa penelitian terkait pembelajaran Matematika yang menggunakan model pembelajaran kooperatif sebagai penunjang penguatan karakter kerja sama. Selanjutnya pembinaan karakter kerja sama melalui pembelajaran Matematika dapat tercapai karena di dukung oleh nilai-nilai karakter lainnya. Kemudian nilai karakter kerja sama yang di bina melalui pembelajaran Matematika bukan hanya dapat meningkatkan hasil belajar, tetapi juga dapat meningkatkan keterampilan komunikasi matematis, pemahaman siswa, penalaran matematis, motivasi belajar, dan kemampuan koneksi matematis.

\section{PEMBAHASAN}

Pendidikan Karakter Kerjasama dalam Pembelajaran Matematika 
Dalam pembelajaran Matematika, menerapkan pendidikan karakter kerjasama sangat menunjang proses pencapaian tujuan pembelajaran. Namun, pendidikan karakter kerjasama dalam pembelajaran Matematika tidak serta merta dapat di lakukan dengan gamblang oleh guru tanpa persiapan. Dalam penerapan pendidikan karakter kerjasama dalam pembelajaran Matematika di kelas membutuhkan model pembelajaran kooperatif untuk menunjang pelaksanaan pendidikan karakter kerjasama agar lebih terarah. Model pembelajaran kooperatif merupakan model pembelajaran yang dalam aktivitasnya melibatkan siswa saling berkerjasama secara aktif untuk mencapai suatu tujuan tertentu (Nurnawati et al., 2012). Model pembelajaran kooperatif memiliki berbagai tipe pembelajaran. Dalam menerapkan pendidikan karakter kerjasama, penting bagi guru untuk memilih tipe model pembelajaran kooperatif yang sesuai dengan materi yang akan diajarkan karena keberhasilan pencapaian tujuan pembelajaran juga tergantung pada perencanaan pembelajaran yang matang.

Beberapa hasil penelitian menjelaskan bahwa model pembelajaran kooperatif sebagai penunjang pelaksanaan pendidikan karakter kerjasama dalam pembelajaran Matematika diantaranya penelitian yang di lakukan oleh (Suprapti, 2016) yaitu model pembelajaran kooperatif tipe STAD (Student Time Achievement Divisions) yang digunakan dalam pembelajaran Matematika materi bangun datar layang-layang, jajargenjang, dan trapesium. Dalam penelitian tersebut dijelaskan bahwa dalam materi geometri menuntut siswa untuk berpikir logis, kerja secara sistematis, menghidupkan kreatifitas, serta dapat mengembangkan kemampuan berinovasi. Sedangkan model pembelajaran kooperatif tipe STAD merupakan tipe pembelajaran kooperatif yang melibatkan siswa secara aktif bekerjasama dalam mengkonstruksi pengetahuan. (Firdaus, 2016) dalam penelitiannya menjelaskan bahwa model kooperatif tipe Snowball Throwing dalam pembelajaran Matematika materi sistem persamaan linear dua variabel (SPLDV) relevan dengan materi SPLDV karena kerjasama yang di bangun dalam model ini adalah jiwa kepemimpinan. (Lestari, 2017) dalam penelitiannya penerapan model kooperatif tipe Group Investigation (GI) dalam pembellajaran matematika materi statistika. Pendidikan karakter kerjasama dalam tipe GI yang dijelaskan dalam penelitian ini dimulai dari siswa bekerjasama dalam menentukan topik diskusi, merencakanan investigasi, melakukan investigasi, merancang presentasi, dan mempresentasikan temuannya. (Atikasari et al., 2018) dalam penelitiannya menggunakan model pembelajaran kooperatif tipe Think, Talk, and Write (TTW) dalam pembelajaran matematika materi trigonometri. Kerjasama yang di lakukan dalam model pembelajaran tipe TTW ini adalah bagaimana siswa memecahkan masalah melalui tiga tahapan yaitu siswa membaca suatu teks permasalahan matematika kemudian membuat catatan kecil mengenai ide selanjutnya siswa mengkomunikasikan ideide mereka dengan diskusi, dan terakhir menuliskan hasil diskusi mereka.

Dari beberapa hasil penelitian di atas, ratarata guru menggunakan model pembelajaran kooperatif sebagai penunjang untuk melaksanakan pendidikan karakter kerjasama dalam pembelajaran Matematika untuk mencapai tujuan pembelajaran. Akan tetapi, setiap model pembelajaran memiliki kekurang termasuk model pembelajaran kooperatif. Beberapa kelemahan dalam model pembelajaran kooperatif dalam pelaksanaannya memang membutuhkan waktu yang lebih banyak untuk pembagian kelompok, prasarana yang tidak memadai, sulitnya membiasakan siswa untuk aktif dalam kelompoknya, dan lain sebagainya.

\section{Nilai-Nilai Karakter Yang Dapat Dikembangkan Melalui Karakter Kerjasama}

Pendidikan karakter kerjasama tentu saja tidak secara otomatis dapat berdiri sendiri, melainkan terdapat nilai-nilai karakter lain sebagai penunjangnya. Sebagaimana dalam pedoman penilaian kurikulum 2013 dijelaskan bahwa terdapat empat karakter yang dicantumkan sebagai indikator pencapaian karakter kerjasama antara lain 
karakter percaya diri, santun, peduli, dan jujur (Yulianti et al., 2016).

Karakter kerjasama dalam pembelajaran Matematika dapat menumbuhkan karakter percaya diri pada siswa untuk mengemukakan pendapatnya, memiliki keberanian, dan memiliki keyakinan dalam dirinya. Selanjutnya karakter santun dalam kerjasama, bagaimana siswa dapat menggunakan kata-kata yang baik ketika mengkritik, saling menghormati, dan saling menghargai.

Karakter lain yang terbentuk melalui kerjasama yaitu karakter peduli pada diri siswa dimana siswa dapat memiliki rasa simpati dan empati kepada sesama teman sekelompoknya karena pada dasarnya dalam suatu kelompok belajar terdapat kemampuan yang berbeda. Terlebih lagi konsep Matematika yang sulit dipahami siswa, sehingga karakter peduli dapat menumbuhkan kepedulian dengan sikap berbagi ilmu dimana siswa yang memiliki kemampuan tinggi akan mengajarkan apa yang telah ia pahami kepada temannya yang belum paham.

Kemudian karakter jujur dalam kerjasama sangat penting karena melalui karakter jujur siswa akan melaporkan hasil kerja kelompok apa adanya, mengakui kesalahan atau kekurangan dari pekerjaan mereka, menjauhkan siswa dari tindakan plagiarisme, dan lain sebagainya.

Namun kerjasama dalam proses pembelajaran tidak hanya dapat mengembangkan empat nilai karakter yang telah dijelaskan di atas, tetapi ada nilai-nilai karakter lain yang paling penting dalam kerjasama adalah tanggung jawab. Sebagaimana kerjasama dalam konteksnya adalah belajar secara bersama-sama untuk menyelesaikan suatu permasalahan. Jadi, semua anggota dalam kelompok belajar memiliki bertanggung jawab yang sama untuk menyelesaikan permasalahan yang diberikan (Tristanti, 2017).

\section{Peningkatan Kemampuan Siswa Melalui Karakter Kerjasama dalam Pembelajaran Matematika}

Pendidikan karakter kerjasama dalam pembelajaran Matematika dapat meningkatkan kemampuan komunikasi matematis, pemahaman matematis, penalaran matematis, dan koneksi matematis.

\section{Komunikasi Matematis}

Kemampuan komunikasi matematis dalam pembelajaran matematika penting bagi siswa, karena Matematika bukan hanya sekedar perhitungan yang mengolah angkaangka semata tetapi Matematika merupakan bahasa dan sebagai aktivitas sosial (Umar, 2012).

Berbagai penelitian yang telah di lakukan terkait kemampuan komunikasi matematis siswa melalui kerjasama dalam pembelajaran Matematika terbukti meningkat. Salah satunya penelitian pembelajaran Matematika pada materi segitiga menggunakan model pembelajaran kooperatif tipe Complete Sentence dan Team Quiz yang dilakukan oleh (Purnama \& Aldila, 2016) menunjukkan bahwa kemampuan komunikasi matematis siswa meningkat setelah pembelajaran di lakukan dengan bekerjasama. Ini dibuktikan dengan hasil belajar siswa yang meningkat melalui pretest dan post test yang diberikan. Skor rata-rata hasil belajar siswa yang di peroleh pada saat pretest di mana pelaksanaan pembelajaran tidak di lakukan siswa dengan kerjasama yaitu sebesar 5,79 dan setelah di lakukan pembelajaran Matematika dengan menekankan pendidikan karakter kerjasama pada siswa skor post test yang diperoleh adalah sebesar 14,23 untuk model kooperatif tipe Complete Sentence. Sedangkan untuk model pembelajaran kooperatif tipe Team Quiz di peroleh ratarata pre test dengan skor 5,82 dan meningkat menjadi 18,13 melalui post test.

\section{Pemahaman Matematis}

Pemahaman berbeda dengan hafalan. Pemahaman lebih bersifat kepada sesuatu yang benar-benar di mengerti terkait konsep dan penerapannya. Sedangkan hafalan bersifat ingatan yang sewaktu-waktu bisa hilang ketika tidak sering di ulang. Pembelajaran Matematika di kelas selalu dikaitkan dengan permasalahan dalam kehidupan sehari-hari. Untuk bisa memecahkan permasalahan dalam konteks 
matematika dibutuhkan pemahaman matematis.

Berbagai penelitian di lakukan terkait kemampuan pemahaman matematis siswa melalui kerjasama dalam pembelajaran Matematika terbukti meningkat. Salah satunya penelitian yang di lakukan oleh (Karubaba et al., 2019) yaitu meningkatkan pemahaman konsep matematis siswa menggunakan model kooperatif tipe Think Pair Square (TPS) dalam pembelajaran Matematika pada materi kubus dan balok. Hasil penelitian menunjukkan bahwa terdapat peningkatan kemampuan pemahaman matematis siswa yang dibuktikan melalui pre test dan post test. Rata-rata nilai pretest kelas eksperimen dan kelas kontrol adalah 34,86 dan 35,40 dari nilai maksimum 100. Berdasarkan hasil pre test menunjukkan bahwa tidak terdapat perbedaan kemampuan pemahaman konsep matematis siswa. Selanjutnya post test diberikan setelah siswa melakukan pembelajaran dengan bekerjasama menggunakan model kooperatif tipe TPS dan hasil post test menunjukkan kelas eksperimen memperoleh rata-rata posttest sebesar 78,85 yang lebih tinggi dibanding kelas kontrol sebesar 49,89. Dari data skor rata-rata hasil belajar siswa terbukti bahwa kemampuan pemahaman matematis siswa meningkat lebih baik melalui pembelajaran secara kooperatif yang melibatkan siswa secara aktif belajar dengan bekerjasama.

\section{Penalaran Matematis}

Dalam pembelajaran Matematika siswa di tuntut untuk dapat membuat generalisasi, kemudian menyusun bukti, dan selanjutnya mampu menjelaskan gagasan atau pandangan dan pernyataan matematika. Untuk dapat melakukan tahapan di atas, penting bagi siswa menguasai kemampuan penalaran matematis. Kemampuan penalaran Matematis tentunya tidak mudah dikuasai oleh sebagian siswa. Namun, dengan karakter kerjasama yang diterapkan oleh guru dapat menjadi solusi agar dapat meningkatkan kemampuan penalaran matematis siswa.

Beberapa hasil penelitian terkait karakter kerjasama dalam pembelajaran Matematika yang dapat meningkatkan penalaran matematis siswa, menunjukkan adanya peningkatan terhadap kemampuan penalaran siswa. Salah satunya penelitian yang di lakukan oleh (Rahmawati, 2017) yang menggunakan model pembelajaran kooperatif tipe Teams Games Tournaments (TGT) dan Number Head Together (NHT) dalam pembelajaran Matematika dapat meningkatkan kemampuan penalaran matematis siswa. Peningkatan kemampuan penalaran matematis siswa yang dihubungkan dengan prestasi belajar siswa. Dari hasil penelitian menunjukkan bahwa terdapat tiga tingkatan kemampuan penalaran matematis siswa yaitu tinggi, sedang, dan rendah. Hasil uji statistik menunjukkan bahwa siswa dengan kemampuanpenalaran matematis tinggi memiliki prestasi belajar yang lebih baik dari pada siswa dengan kemampuan penalaran matematis sedang yang dibuktikan dengan skor nilai kemampuan penalaran matematis tinggi sebesar 69,17 sedangkan nilai kemampuan penalaran matematis sedang sebesar 61,12. Selanjutnya siswa dengan kemampuan penalaran matematis tinggi memiliki prestasi belajar yang lebih baik dari pada siswa dengan kemampuan penalaran matematis rendah yang ditunjukkan dengan skor nilai kemampuan tinggi sebesar 69,17 sedang skor kemampuan penalaran matematis rendah sebesar 55,71. Kemudian siswa dengan kemampuan penalaran matematis sedang memiliki prestasi belajar yang lebih baik dari siswa dengan kemampuan penalaran matematis rendah. Ini di tunjukkan dengan skor nilai kemampuan matematis sedang sebesar 61,12 sedangkan nilai siswa dengan kemampuan penalaran matematis rendah 55,71.

Dari pemaparan skor nilai kemampuan penalaran matematis siswa di atas, dapat disimpulkan bahwa:

$\operatorname{PMT}(69,17)>$ PMS $(61,12)$

$\operatorname{PMT}(69,17)>\operatorname{PMR}(55,71)$

PMS $(61,12)>$ PMR $(55,71)$

artinya semakin tinggi kemampuan penalaran matematis siswa maka prestasi belajar siswa akan semakin baik dan pembelajaran Matematika yang di lakukan siswa dengan bekerjasama dapat membantu 
siswa dalam meningkatkan kemampuan penalaran matematis yang baik.

\section{Koneksi Matematis}

Kemampuan koneksi matematis sangat penting bagi siswa dalam pembelajaran Matematika agar siswa mampu memecahkan masalah dan mengaplikasikan konsep matematika dalam kehidupan seharihari.

Berbagai penelitian yang telah di lakukan terkait kemampuan koneksi matematis siswa melalui kerjasama dalam pembelajaran Matematika terbukti meningkat. Salah satunya penelitian yang di lakukan oleh (Muchlis et al., 2018) yaitu meningkatkan kemampuan koneksi matematis siswa melalui pembelajaran kooperatif tipe Number Head Together (NHT) yang dibuktikan dengan hasil belajar melalui pre test dan post test. Hasil pre test menunjukkan terdapat perbedaan rata-rata sebesar 0,3 dimana ratarata nilai pretes kelas eksperimen adalah 8,11 dan kelas kontrol adalah 7,81. Ini berarti menunjukkan bahwa rata-rata kemampuan awal siswa dari dua kelas tidak jauh berbeda. Selanjutnya hasil post test menunjukkan perbedaan 4,08 dimana post test kelas eksperimen mendapatkan rata-rata 13,24 dan kelas kontrol 9,16. Ini menunjukkan bahwa kelas eksperimen mendapatkan rata-rata kemampuan koneksi lebih baik.

Dari hasil penelitian yang di atas, menunjukkan bahwa pembelajaran Matematika yang di lakukan siswa dengan bekerjasama dapat meningkatkan kemampuan koneksi matematis yang jauh lebih baik datipada siswa belajar sendirisendiri.

\section{SIMPULAN}

Berdasarkan telaah literatur yang telah penulis lakukan, dapat disimpulkan beberapa hal terkait pendidikan karakter kerjasama dalam pembelajaran Matematika yaitu pertama, pendidikan karakter kerjasama yang dalam penerapannya melibatkan siswa berinteraksi dalam suatu kelompok belajar di lakukan dengan menggunakan model pembelajaran kooperatif. Guru dapat menggunakan model pembelajaran kooperatif tipe apa pun yang sesuai dalam pembelajaran
Matematika sebagai penunjang pelaksanaan pendidikan karakter kerjasama dalam pembelajaran Matematika menjadi lebih terarah. Kedua, pendidikan karakter kerjasama dalam pembelajaran Matematika secara tidak langsung dapat menumbuhkan nilai-nilai karakter lainnya seperti tanggung jawab, menghargai prestasi, peduli sosial, dan lain sebagainya karena suatu kelompok belajar setiap anggota harus menyatukan segala perbedaan untuk mencapai tujuan yang sama. Ketiga, pendidikan karakter kerjasama dalam pembelajaran Matematika dapat meningkatkan empat kemampuan yang harus dikuasai oleh siswa dalam pembelajaran Matematika yaitu kemampuan komunikasi matematis, pemahaman matematis, penalaran matematis, dan koneksi matematis yang dibuktikan melalui pre test dan post test yang diberikan untuk melihat perbedaan hasil belajar siswa sebelum dan sesudah.

\section{DAFTAR RUJUKAN}

Alwasilah, A. Chaedar. Islam, Culture, and Education. Bandung: PT. Remaja Rosdakarya, 2015.

Atikasari, G., Agoestanto, A., \& Winanti, K. Meningkatkan berpikir kreatif matematis dan kerjasama melalui model pembelajaran kooperatif strategi TTW berbantuan kartu soal materi trigonometri SMAN 5 Semarang. Prisma, 1, P: 601-607, 2018.

Fadhilaturrahmi. Pengaruh Pembelajaran Kooperatif Tipe Stad Dan Gi Terhadap Peningkatan Kemampuan Koneksi Matematik Siswa Sekolah Dasar. Jurnal Basicedu, 2(1), 160-165, 2018. https://doi.org/10.31004/basicedu.v2i1. 38

Fauzani, R. A. Pelaksanaan Pendidikan Karakter Kerjasama Dalam Implementation Of Cooperation In Character Education In PE Learning. Jurnal Pendidikan Guru Sekolah Dasar, 7(24), P: 350-361, 2018.

Firdaus, A. M. Efektivitas Pembelajaran Matematika melalui Penerapan Model Pembelajaran Kooperatif Tipe Snowball Throwing. Beta Jurnal Tadris Matematika, 9(1), P: 61, 2016. https://doi.org/10.20414/betajtm.v9i1.1 
Hakam, K. A. \& Nurdin, E. S. Metode Internalisasi Nilai-Nilai Untuk Memodifikasi Perilaku Berkarakter. Bandung: Maulana Media Grafika, 2016.

Karubaba, S. A. M., Rahman, B., \& Arifin, S. Pengaruh Model Pembelajaran Kooperatif Tipe Think Pair Square Terhadap Kemampuan Pemahaman Konsep Matematis Siswa. IndoMath: Indonesia Mathematics Education, 2(1), $\mathrm{P}$ : 2016.https://doi.org/10.30738/indomath .v2i1.3150

Komalasari, K. The Effect of Contextual Learning in Civic Education on Students' Civic Competence. Journal of Social Sciences, 5(4), P: 261-270, 2012.https://doi.org/10.3844/jssp.2009. 261.270

Kesuma, D. Pendidikan Karakter Kajian Teori Dan Praktik Di Sekolah. Bandung: PT. Remaja Rosdakarya Offset, 2012.

Kusuma, A. W. Meningkatkan Kerjasama Siswa dengan Metode Jigsaw. Konselor, 7(1), P: 26-30, 2018. https://doi.org/10.24036/02018718458$0-00$

Lestari, S. Penerapan Pembelajaran Group Investigation Untuk Meningkatkan Prestasi Dan Keaktifan Siswa Materi Statistika. Journal of Medives, 1(2), P: 150-157, 2017. http://e-journal.ikip veteran.ac.id/index.php/matematika

Lickona, Thomas. Educating For Character. Jakarta: Bumi Aksara, 2019.

Linuhung, Nego. dan Sudarman, Satrion Wicaksono. Pengaruh Pembelajaran Kooperatif Tipe Group Investigation (GI) Terhadap Kemampuan Penalaran Matematis Siswa MTs. Jurnal Pendidikan Matematika. Vol. 5, No. 1, P: 1-8, 2019.

Lonto, A. L., Wua, T. D., Pangalila, T., \& Sendouw, R. Moral work, teaching profession and character education in Forming Students' Characters. International Journal of Engineering and Technology(UAE), 7(4), P: 99-103, 2018.

https://doi.org/10.14419/ijet.v7i4.28.22
560

Masjudin. Pembelajaran Kooperatif Investigatif Untuk Meningkatkan Pemahaman Siswa Materi Barisan dan Deret. Jurnal Edukasi Matematika Dan Sains, 4(2), P: 76-84, 2016.

Muchlis, A., Komara, E. S., Kartiwi, W., Nurhayati, N., Hendriana, H., \& Hidayat, W. Meningkatkan Koneksi Matematis Siswa Smp Melalui Pendekatan Open-Ended Dengan Setting Kooperatif Tipe NHT. KALAMATIKA Jurnal Pendidikan Matematika, 3(1), P: 81-92, 2018. https://doi.org/10.22236/kalamatika.vol 3no1.2018pp81-92

Nurnawati, E., Yulianti, D., \& Susanto, H. Peningkatan Kerjasama Siswa SMP Melalui Penerapan Pembelajaran Kooperatif Pendekatan Think Pair Share. Unnes Physic Education Journal, 1(2257), 2012.

Purnama, I. L., \& Aldila, E. Kemampuan Komunikasi Matematis Siswa Ditinjau Melalui Model Pembelajaran Kooperatif Tipe Complete Sentence Dan Team Quiz. Jurnal Pendidikan Matematika, 10(1), 27-43, 2016. https://doi.org/10.22342/jpm.10.1.3267. 26-41

Rahmawati, N. K. Implementasi Teams Games Tournaments dan Number Head Together ditinjau dari Kemampuan Penalaran Matematis. Al-Jabar: Jurnal Pendidikan Matematika, 8(2), P: 121, 2017.

https://doi.org/10.24042/ajpm.v8i2.158 5

Rosyidah, U. Pengaruh Model Pembelajaran Kooperatif Tipe Jigsaw terhadap Hasil Belajar Matematika Siswa Kelas VIII SMP Negeri 6 Metro. SAP (Susunan Artikel Pendidikan), 1(2), P: 115-124, 2016.

https://doi.org/10.30998/sap.v1i2.1018

Sardadevi, N., \& Winarti, A. Keefektivan Strategi Pembelajaran Kolaboratif Terintegrasi Multiple Intelligence Dalam Pengembangan Kemampuan Kerjasama, Motivasi Dan Hasil Belajar Kognitif Pada Materi Hidrolisis Garam Siswa kelas XI IPA SMAN 11 
Banjarmasin. Journal of Chemistry And Education, Vol.1, No.2, P: 195-203, 2017.

Suprapti, E. Pengembangan Perangkat Pembelajaran Matematika Model Kooperatif Tipe STAD dengan Media Powerpoint Ispring pada Materi Jajargenjang, Layang-Layang dan Trapesium di Kelas VII SMP. Journal of Mathematics Education, Science and Technology, 1(1), P: 57, 2016. https://doi.org/10.30651/must.v1i1.98

Tafsir, Ahmad. Pendidikan Karakter Perspektif Islam. Bandung: PT. Rosdakarya, 2017.

Tristanti, L. B. Pengaruh Model Pembelajaran Kooperatif Tipe Team Assisted Individualization (TAI) Dan Problem Based Learning (PBL) Terhadap Pemahaman Konsep Bangun Ruang siswa. Jurnal Pendidikan Matematika FKIP, Vo. 6, No. 3, P: 1-10, 2017. https://doi.org/10.1037/00223514.51.6.1173

Umar, W. Membangun Kemampuan Komunikasi Matematis Dalam Pembelajaran Matematika. Infinity Journal, 1(1), P: 1, 2012. https://doi.org/10.22460/infinity.v1i1.2

Williams, M. M. Models of Character Education: Perspectives and Developmental Issues. The Journal of Humanistic Counseling, Education and Development, 39(1), P: 32-40, 2000. https://doi.org/10.1002/j.2164490x.2000.tb00091.x

Yulianti, S. D., Djatmika, E. T., \& Susanto, A. Pendidikan Karakter Kerja Sama Dalam Pembelajaran Siswa Sekolah Dasar Pada Kurikulum 2013. Jurnal Teori Dan Praksis Pembelajaran IPS, 1(1), P: 33-38, 2016.https://doi.org/10.17977/um022v1 i12016p033 